\title{
EVALUASI KOMPETENSI PROFESIONAL GURU IPS PADA MTS DI KECAMATAN MRANGGEN KABUPATEN DEMAK
}

\author{
Sofyani \\ MTs Sholihiyyah \\ Sofyani1980@gmail.com
}

DOI : http://doi.org/10.37730/edutrained.v5i1.130

Diterima: 10 Maret 2021 | Disetujui: 14 Juni 2021 | Dipublikasikan: 6 Juli 2021

\begin{abstract}
Abstrak
Data referensi kemdikbud menunjukkan kecamatan Mranggen merupakan kecamatan dengan jumlah sekolah terbanyak di kabupaten Demak dengan jumlah 15 SMP dan 24 MTs. Dari pengamatan sementara, masih banyak guru IPS pada MTs di Kecamatan Mranggen tidak menguasai pembelajaran yang baik pada saat proses pembelajaran berlangsung. Penelitian ini berusaha mengetahui kompetensi profesioanl guru IPS dan bagaimana faktor latar belakang individual mempengaruhi kompetensi profesioanl tersebut. Penelitian ini merupakan jenis penelitian evaluasi, dengan menggunakan model evaluasi Banchmarking. Populasi dan sampel penelitian adalah seluruh guru IPS pada MTs di Kecamatan Mranggen yang berjumlah 31 orang. Tehnik analisis data yang dipergunakan adalah analisis kuantitatif. Langkah analisis data penelitian ini adalah analisis data deskriptif dan uji regresi. Hasil penelitian menunjukkan 32,2\% guru memiliki kompetensi profesional kategori amat baik, 25,8\% dengan kategori baik, dan 34.4\% dengan kategori cukup. Hasil regresi menunjukkan terdapat pengaruh dari faktor individual guru terhadap pembentukan kompetensi profesional guru IPS pada MTs di Kecamatan Mranggen. Pengalaman mengajar memiliki pengaruh yang paling besar dalam pembentukan kompetensi profesional guru yaitu sebesar 44,63\%, selanjutnya lingkungan kerja $31,16 \%$, latar belakang pendidikan $25,80 \%$ dan pengalaman pelatihan sebesar $0,35 \%$. Hasil penelitian menunjukkan pelatihan memiliki prosentase terkecil dalam pembentukan kompetensi professional guru IPS, diharapkan pemberian pelatihan yang lebih intensif mampu meningkatkan kompetensi profesional guru.
\end{abstract}

Kata Kunci: Evaluasi, Kompetensi Profesional, Guru IPS

\begin{abstract}
Data Reference of Ministry of Education and culture shows Mranggen sub-district is the subdistrict with the largest number of schools in Demak district with 15 SMP and 24 MTs. From temporary observations, there are still many social studies teachers at MTs in Mranggen District who do not master good learning during the learning process. This study seeks to determine the professional competence of social studies teachers and how individual background factors affect the professional competence. This research is a type of evaluation research, using the Banchmarking evaluation model. The population and research sample were all IPS teachers at MTs in Mranggen District, amounting to 31 people. The data analysis technique used is quantitative analysis. The data analysis step of this research is descriptive data analysis and regression test. The results showed that $32.2 \%$ of the teachers had professional competence in the very good category, $25.8 \%$ in the good category, and $34.4 \%$ with the sufficient category. The regression results show that there is an effect of individual teacher factors on the formation of the professional competence of social studies teachers at MTs in Mranggen District. Teaching experience has the greatest influence in the formation of teacher professional competence, namely $44.63 \%$, then the work environment is $31.16 \%$, educational background is $25.80 \%$ and training experience is $0.35 \%$. The results showed that training has the smallest percentage in the formation of the
\end{abstract}


professional competence of social studies teachers. It is hoped that more intensive training can improve the professional competence of teachers.

Keywords : Evaluation, professional competence, social studies teacher

\section{PENDAHULUAN}

Pendidikan merupakan hal yang terpenting dalam kehidupan, ini berarti bahwa setiap manusia berhak mendapat dan berharap untuk selalu berkembang dalam pendidikan. Menurut Undang-Undang Nomor 20 tahun 2003 tentang Sistem Pendidikan Nasional, Pasal 3, bahwa tujuan pendidikan nasional adalah mengembangkan potensi peserta didik agar menjadi manusia yang beriman dan bertaqwa kepada Tuhan yang Maha Esa, berakhlak mulia, sehat, berilmu, cakap, kreatif, mandiri, dan menjadi warga negara yang demokratis serta bertanggung jawab.

Meningkatkan profesionalisme guru merupakan hal yang sangat penting, karena menyangkut masalah hasil kerja guru yang merupakan salah satu langkah dalam meningkatkan mutu pelayanan kepada siswa. Tetapi disisi lain terdapat asumsi yang mengatakan bahwa kemerosotan dalam dunia pendidikan disebabkan karena kurangnya kemampuan profesionalisme guru, maka dari itu demi peningkatan mutu pendidikan sangat dibutuhkan tenaga pengajar atau pendidik yang memiliki kompetensi atau pemenuhan profesionalisme (Mulyasa, 2008 : 39). Sedangkan Menurut Nasanius dalam Pupuh Fathurrohman dan Aa Suryana (2012 : 39) mengatakan bahwa kemerosotan pendidikan bukan hanya diakibatkan oleh kurikulumnya tetapi juga kurangnya profesionelisme guru dan keengganan belajar siswa.

Profesionalisme guru berkaitan erat dengan output hasil pendidikan yang diharapkan masyarakat. Berbagai upaya pemerintah dilakukan untuk menghasilkan sumber daya manusia yang berkualitas. Beragam mata pelajaran disusun dalam kurikulum guna memperoleh hasil out put pendidikan yang berkuaitas.

Artikel ini berfokus pada kompetensi profesional guru IPS, dimana IPS penting untuk dipelajari karena tujuan dari pendidikan IPS diarahkan pada pembentukan sikap dan kepribadian profesional serta peningkatan penguasaan pengetahuan dan keterampilan fungsional peserta didik (Suwito, 2008 : 31). Lebih lanjut IPS dilaksanakan dengan orientasi agar terjadi transfer of value dan bukan semata-mata transfer of knowledge (Suwito, 2008 : 32). Berdasarkan uraian tersebut maka kompetensi profesional menjadi suatu hal yang sangat penting untuk dimiliki oleh seorang guru mata pelajaran IPS, dalam rangka mengantarkan peserta didik pada peningkatan penguasaan pengatahuan sosial dan pembentukan sikap.

Tulisan berusaha untuk mengetahui kompetensi profesioanl guru IPS dan mengetahui bagaimana faktor latar belakang individual dapat mempengaruhi kompetensi profesioanl tersebut. Hal ini akan membawa berbagai manfaat diantaranya sebagai bahan masukan guru IPS untuk mengetahui faktorfaktor pembentuk profesionalisme guru serta mengantisipasi kendala-kendala yang dihadapi dalam meningkatkan kompetensi profesional, sebagai bahan masukan bagi sekolah dalam upaya meningkatkan profesionalisme guru, agar menjadi lebih baik dan sebagai bahan masukan dan evaluasi dalam pengambilan kebijakan guna meningkatkan kualitas sumber daya manusia bagi pemerintah terutama untuk meningkatkan kompetensi profesional guru.

\section{KAJIAN PUSTAKA}

\section{Evaluasi}

Evaluasi merupakan perbandingan kuantitatif dari alternatif-alternatif rencana 
pada hasil yang aktual atau potensial dari tujuan dan sasaran yang dipilih (Kaiser, et al, 1995:426). Menurut wandt and brown dalam sudijono (2003 :1) evaluasi adalah "Evaluation is refer to the act ot the process to determining the value of something " yang berarti Evaluasi menunjukkan pada tindakan atau proses untuk menentukan nilai akan sesuatu.

Evaluasi adalah tindakan mengamati dan melakukan investigasi efektifitas program, serta menilai kontribusi program terhadap perubahan dan menilai kebutuhan untuk perbai.kan, kelanjutan atau perluasan program. Selanjutnya mengenai evaluasi sistem informasi yaitu suatu proses untuk menggali dan mencari tahu, tentang sejauh mana suatu ke.giatan implementasi sistem informasi, baik dari sudut pandang persepsi pengguna, organisasi, maupun dari segi teknologi sistem informasinya (Hakam, 2016).

\section{Kompetensi Profesional}

Profesi guru menurut National EducationAsosiation adalah jabatan yang melibatkan kegiatan intelektual, menggeluti ilmu khusus, memerlukan persiapan yang lama dan latihanterus-menerus, kegiatan nirlaba, dan mempunyai organisasi profesi yang kuat. Menurut Supriyadi, untuk menjadi guru dituntut memiliki lima hal sebagai berikut: a) guru memiliki komitmen kepada siswa dan proses belajarnya, b) guru menguasai secara mendalam bahan atau mata pelajaran yang diajarkannya serta cara mengajarnya kepada siswa melalui berbagai cara evaluasi, d) guru mampu berfikir sistematis tentang apa yang dilakukan oleh dan belajar dari pengalamannya, dan 5) guru seyogyanya merupakan bagian dari masyarakat belajar dalam lingkungan profesi.

Guru yang profesional adalah guru yang memiliki seperangkat kompetensi (pengetahuan, ketrampilan, perilaku) yang harus dimiliki, dihayati, dan dikuasai oleh guru dalam melaksanakan tugas keprofesionalannya (Saud, 2011: 49).Selanjutnya guru profesional menurut Kunandar (2007: 47) adalah orang yang memiliki kemampuan dan keahlian khusus dalam bidang keguruan sehingga ia mampu melakukan tugas dan fungsinya sebagai guru dengan kemampuan maksimal.

Profesionalisme adalah sebutan yang mengacu kepada sikap mental dalam bentuk komitmen dari para anggota suatu profesi untuk senantiasa mewujudkan dan meningkatkan kualitas profesionalnya (Suyanto dan Djihad 2012: 25). Menurut Saud (2011: 7), "Profesi diartikan sebagai suatu jabatan atau pekerjaan yang menuntut keahlian (expertise) dari para anggotanya. Sedangkan Profesional menunjuk pada orang atau penampilan seseorang yang sesuai dengan tuntutan yang seharusnya (Hendri, 2010: 2).

Jadi profesi adalah suatu pekerjaan atau jabatan yang menuntut keahlian tertentu. Artinya suatu pekerjaan atau jabatan yang disebut profesi tidak dapat dipegang oleh sembarang orang, tetapi memerlukan persiapan melalui pendidikan dan pelatihan secara khusus. Dengan adanya kriteria profesionalisme guru tersebut, perlu adanya paradigma baru untuk melahirkan profil guru Indonesia yang profesional di abad ke-21, yaitu: memiliki kepribadian yang matang dan berkembang, penguasaan ilmu yang kuat, keterampilan untuk membangkitkan peserta didik kepada sains dan teknologi, pengembangan profesi serta berkesinambungan.

\section{Latar Belakang Individual Guru IPS}

Latar belakang individual guru merupkan hal -hal yang membentuk karakter seorang guru secara individu baik dari faktor internal maupun faktor eksternal. Dalam pembentukan kompetensi profesional guru terdapat beberapa hal yang dapat diajukan sebagai acuan dalam pembentukan kompetensi profesional tersebut secara individu yaitu:

\section{a. Latar Belakang Pendidikan}

Salah satu tolak ukur guru dapat dikatakan profesional atau tidak, semakin tinggi latar belakang pendidikan seorang guru maka diharapkan semakin tinggi pula tingkat profesionalismenya, karena latar belakang 
pendidikan akan menentukan kepribadian seseorang, termasuk dalam hal ini pola pikir dan wawasannya, faktor inilah yang akan banyak mempengaruhi profesionalisme mengajar seorang guru.

Kualitas pendidikan guru sangat menentukan dalam penyiapan sumber daya manusia yang handal. Menurut Peraturan Pemerintah Nomor 19 Tahun 2005 pasal 28, bahwa "pendidik harus memiliki kualifikasi akademik dan kompetensi sebagai agen pembelajaran, sehat jasmani dan rohani, serta memiliki kemampuan untuk mewujudkan tujuan pendidikan nasional".Kualifikasi akademik sebagaimana dimaksud adalah latar belakang pendidikan minimal yang harus dipenuhi oleh seorang pendidik yang dibuktikan dengan ijazah dan/atau sertifikat keahlian yang relevan sesuai ketentuan perundangundangan yang berlaku. Latar belakang pendidikan guru dapat dilihat dari dua sisi, yaitu kesesuaian antara bidang ilmu yang ditempuh dengan bidang tugas dan jenjang pendidikan. Untuk profesi guru sebaiknya juga berasal dari lembaga pendidikan guru. C. V. Good (dalam Ahmad Barizi,2009: 142) berpendapat bahwa guru pemula dengan latar Pendidikan keguruan lebih mudah menyesuaikan diri dengan lingkungan sekolah, karena dia sudah dibekali dengan seperangkat teori sebagai pendukung pengabdiannya, sedangkan guru yang bukan berlatar pendidikan keguruan akan banyak menemukan banyak masalah dalam pembelajaran. Jenis pekerjaan yang berkualifikasi profesional memiliki ciri-ciri tertentu, diantaranya memerlukan persiapan/ pendidikan khusus bagi calon pelakunya,yaitu membutuhkan pendidikan prajabatan yang relevan.

Latar belakang pendidikan seorang guru akan berpengaruh terhadap praktek pembelajaran dikelas, seperti penentuan cara mengajar serta melakukan evaluasi. Latar belakang pendidikan juga dapat dijadikan sebagai salah satu patokan guru profesional, hal ini dikarenakan latar belakang pendidikan sangat banyak pengaruhnya terhadap tingginya kompetensi pedagogik yang dimiliki oleh guru, menurut Sudarwan Danim (2002: 30) "Seorang guru dikatakan profesional atau tidak, dapat dilihat dari dua perspektif. Pertama, latar belakang pendidikan, dan kedua, penguasaan guru terhadap materi bahanajar, mengelola pembelajaran, mengelola siswa, melakukan tugas bimbingan dan lain-lain."

Seiring dengan perkembangan zaman dan era globalisasi yang menuntut profesionalisme guru, maka semua guru diharapkan berpendidikan minimal S1. PP No. 19 Tahun 2005, pasal 28 ayat 1 mengaris bawahi bahwa pendidik harus memiliki kualifikasi akademik dan kompetensi sebagai agen pembelajaran, sehat jasmani dan rohani, serta memiliki kemampuan untuk mewujudkan tujuan pendidikan nasional.

\section{b. Pengalaman Mengajar}

Menurut Suyatno

(2008:111), pengalaman mengajar yaitu masa kerja guru dalam melaksanakan tugas sebagai pendidik pada satuan pendidikan tertentu sesuai dengan surat tugas dari lembaga yang berwenang (dapat dari pemerintah, dan/atau kelompok masyarakat penyelenggara pendidikan). Bukti fisik dari komponen ini dapat berupa surat keputusan/surat keterangan yang sah dari lembaga yang berwenang.

Suyatno (2008:11-12) mengemukakan cara mengukur masa kerja dan jam wajib mengajar. Masa kerja dihitung selama seseorang menjadi guru. Bagi guru PNS, masa kerja dihitung mulai dari diterbitkannya surat keterangan melaksanakan tugas berdasarkan SK CPNS. Bagi guru non PNS, masa kerja dihitung selama guru mengajar yang dibuktikan dengan Surat Keputusan dari Sekolah berdasarkan surat pengangkatan dari yayasan. Adapun cara mengukur jam wajib mengajar guru ialah sebagai berikut. Menurut UGG dan Permendiknas, jumlah jam wajib mengajar guru adalah 24 jam tatap muka. Jika guru tersebut tidak dapat memenuhi jam wajib mengajarguru dapat melakukan: 
1. Mengajar di sekolah lain yang memiliki ijin operasional Pemerintah atau Pemerintah Daerah.

2. Melakukan Team Teaching (dengan mengikuti kaidah-kaidah team teaching)

Guru yang dengan alasan tertentu sama sekali tidak dapat memenuhi kewajiban mengajar 24 jam, misalnya guru yang mengajar di daerah terpencil, menurut Permendiknas No. 18 Tahun 2007 pasal 6 ayat (4), guru tersebut harus mendapat persetujuan tertulis dari Menteri Pendidikan Nasional atau pejabat yang ditunjuk. Menurut Suyatno (2008:38), masa kerja atau pengalaman mengajar dihitung sejak yang bersangkutan bekerja sebagai guru baik sebagai PNS maupun non PNS. Bagi guru non PNS harus ada bukti fisik bahwa yang bersangkutan mengajar pada sekolah tersebut.

Berdasarkan uraian di atas, dapat disimpulkan bahwa pengalaman mengajar ditandai dengan kurun waktu. Pengalaman mengajar guru dapat diukur dari jumlah tahun lamanya ia mengajar.

\section{c. Pengalaman Pelatihan}

Suyatno (2008:111) mengemukakan pelatihan yaitu kegiatan yang dilakukan dalam rangka pengembangan atau peningkatan kompetensi dalam melaksanakan tugas sebagai pendidik, baik pada tingkat kecamatan, kabupaten/kota, provinsi, nasional, maupun internasional. Bukti fisik komponen ini dapat berupa sertifikat, piagam, atau surat keterangan dari lembaga penyelenggara diklat.

Menurut Jejen (2011:61), pelatihan memiliki pengaruh yang sangat signifikan terhadap efektifitas sebuah sekolah. Pelatihan memberi kesempatan kepada guru untuk mendapatkan pengetahuan, keterampilan dan sikap baru yang mengubah perilakunya, yang pada akhirnya akan meningkatkan prestasi belajar siswa. Pelatihan harus sesuai dengan kebutuhan guru mengajar. Penyelenggara harus merencanakan dengan matang setiap pelatihan, mulai dari pemilihan materi, waktu, tempat, metode hingga kualitas instruktur.
Berdasarkan peraturan menteri Negara pendayagunaan aparatur Negara dan reformasi birokrasi Nomor 16 Tahun 2009 dijelaskan bahwa pengembangan keprofesian berkelanjutan adalah pengembangan kompetensi guru yang dilaksanakan sesuai dengan kebutuhan, bertahap, berkelanjutan untuk meningkatkan profesionalitasnya. Pelatihan merupakan salah satu upaya untuk mengembangkan profesionalitas guru. Angka kredit adalah satuan nilai dari tiap butir kegiatan dan/atau akumulasi nilai butir-butir kegiatan yang harus dicapai oleh seorang guru dalam rangka pembinaan kepangkatan dan jabatannya.

\section{d. Lingkungan Kerja}

Istilah yang kaitannya erat dengan lingkungan adalah ekologi atau sering disebut dengan lingkungan hidup. Ekologi menurut Oemar Hamalik (2003: 195) terdiri dari bioekologi, geo-ekologi, dan kultur-ekologi. "Bioekologi mencakup unsur lingkungan yang hidup meliputi manusia, tumbuh-tumbuhan dan binatang. Geo-ekologi mencakup alam seperti bumi, air, matahari dan sebagainya. Kultur-ekologi mencakup budaya dn teknologi".

Menurut Oemar Hamalik (2003: 195), Lingkungan adalah sesuatu yang ada di alam sekitar yang memiliki makna dan/atau pengaruh tertentu kepada individu". Sejalan dengan Oemar Hamalik, F. Patty dalam Baharuddin (2009: 68-69) menyatakan:

"Lingkungan merupakan sesuatu yang mengelilingi individu di dalam hidupnya, baik dalam bentuk lingkungan fisik seperti orang tua, rumah, kawan bermain dan masyarakat sekitar, maupun dalam bentuk lingkungan psikologis seperti perasaan yang dialami, cita-cita, persoalan yang dihadapi dan lain sebagainya".

Jika dihitung, banyak sekali lingkungan yang menyertai seorang individu, dengan berbagai latar persoalan dan kondisi yang berbeda-beda. Namun pada hakekatnya lingkungan aktual (sebenarnya) hanyalah sebatas faktor-faktor dalam dunia sekitar 
yang benar-benar mempengaruhi (Baharuddin, 2009: 69).

Siswanto Sastrohadiwiryo (2005: 32) menyebutkan bahwa "Iklim kerja merupakan suatu kondisi, situasi, dan keadaan kerja yang menimbulkan tenaga kerja memiliki semangat dan moral/kegairahan yang tinggi, dalam rangka meningkatkan produktivitas kerja sesuai dengan yang diharapkan". Iklim kerja menyangkut lingkungan organisasi kerja, yaitu keseluruhan sumber daya yang tersedia, baik yang merupakan sumber daya manusia atau bukan manusia, serta pengelompokkan tugas, wewenang, dan tanggung jawab sedemikian rupa sehingga tercipta suatu organisasi yang dapat digerakkan sebagai suatu kesatuan untuk mencapai tujuan yang telah ditetapkan.

Lingkungan kerja berdasarkan pengertian yang disebutkan sebelumnya berarti merupakan faktor yang berada di sekitar manusia yang benar-benar memberikan pengaruh pada pekerjaannya. Guru sebagai seorang pendidik di suatu lembaga sekolah memiliki banyak faktor lingkungan yang mempengaruhi pekerjaannya. Lingkungan kerja guru merupakan lingkungan sekolah sebagai lembaga pendidikan. Di sekolah terdapat berbagai faktor yang termasuk dalam lingkungan kerja seorang guru, antara lain lingkungan fisik sekolah, kepala sekolah, rekan guru lain, karyawan, peserta didik, sarana dan prasarana sekolah, kondisi nonfisik lingkungan sekolah dan birokrasi sekolah. Kesemua factor lingkungan kerja tersebut secara langsung maupun tidak langsung akan berpengaruh dalam kinerja guru, terutama dalam pengembangan kreativitas guru.

Beberapa penelitian telah dilakukan berkaitan dengan profesionalisme guru, diantaranya yaitu Nur kholisah (2017) dalam penelitiannya menunjukkan bahwa profesionalitas guru pendidikan islam paska sertifikasi di MTs negeri Binjai meliputi kompetensi pedagogik, sosial dan professional telah baik.Kendala yang dihadapi dalam upaya peningkatan profesional guru pendidikan agama islam adalah rendahnya frekuensi pelatihan guru danbeban administrasi guru yang semakin berat.

Fitriani, Murniati, dan Usman (2017)

Kompetensi Professional guru dalam pengelolaan pembelajaran di MTs Muhammadiyah banda aceh. Dalam penelitian ini menunjukkan bahwa kompetensi guru yang dimiliki guru dalam merencanakan pembelajaran dalam menyusun RPP,silabus,media, sumber pembelajaran dan evaluasi pembelajaran sesuai petunjuk yang ditetapkan, tetapi ada guru yang mengajar tidak membuat perencanaan pembelajaran,Strategi professional guru dalam mengimplementasikan pembelajaran yaitu: mengetahui materi,struktur,konsep, dan pola pikir keilmuan yang mendukung mata pelajaran yang diajarkan.dan Evaluasi pembelajaran yang diberikan guru sesuai dengan tujuan yang telah ditetapkan.

Tiara Anggia dewi (2015) menemukan bahwa berdasarkan hasil analisis data menunjukkan secara parsial profesionalisme guru berpengaruh positif dan signifikan terhadap kinerja guru ekonomi dengan nilai sig. $t$ sebesar $(0,000)<\alpha(0,05)$ dan thitung $(4,361)>t$ tabel $(1,666)$. Analisis pengaruh motivasi kerja terhadap kinerja guru ekonomi secara parsial berpengaruh positif dan signifikan dengan nilai sig. t sebesar $(0,000)<$ $\alpha(0,05)$ dan thitung $(3,650)>\mathrm{t}$ tabel $(1,666)$. Secara simultan profesionalisme guru dan motivasi kerja berpengaruh positif dan signifikan terhadap kinerja guru ekonomi dengan nilai sig. F sebesar $(0,000)<\alpha(0,05)$.

Penelitian Johanes Konig (2016) yang mengevaluasi kompetensi profesional guru bahasa inggris dengan menerapkan tes dengan standar untuk secara langsung menilai pengetahuan konten (CK), pengetahuan konten pedagogis (PCK), dan umum pengetahuan pedagogis (GPK) guru pra-layanan untuk TEFL di Jerman dari berbagai program dan tahap selama awal pendidikan guru (selama studi master di universitas dan pada akhir fase induksi mereka). Analisis struktural memberikan 
bukti bahwa pengetahuan guru sehubungan dengan TEFL adalah konstruk multidimensi dan PCK terkait erat denganbaik CK dan GPK.

Penelitian Tuba Gökmenoğlu, Christopher M. Clark (2015) menunjukkan bahwa pengalaman mengajar memiliki sebuah pengaruh signifikan secara statistik pada pendapat guru tentang peserta, konten, instruktur,organisasi, pusat pelatihan, dan evaluasi program pelatihan guru. Namun demikian ukuran pengaruh pengalaman mengajar pada penilaian guru sangat kecil. Demikian pula halnya dengan gender, efek signifikan secara statistik hanya pada organisasi dan evaluasi pelatihan program, dan juga efek kecil. Meski pengalaman mengajar tidak memiliki efek yang signifikan secara statistikpada penilaian guru. Dalam terang temuan ini, dimungkinkan untuk menyimpulkan bahwa ada konsensus pendapat guru Turki tentang evaluasi pelatihan dalam jabatanprogram yang tidak berbeda dengan tahun pengalaman mengajar, jenis kelamin atau materi pelajaran spesialisasi.

\section{METODE PENELITIAN}

Penelitian ini merupakan jenis penelitian evaluasi. Pendekatan penelitian yang digunakan dalam penelitian ini adalah kuantitatif. Penelitian ini menggunakan model evaluasi Banchmarking yaitu hasil penelitian yang diperoleh akan dibandingkan dengan standar kompetensi profesional guru yang berlaku di Indonesia.

Populasi dalam peneitian ini adalah seluruh guru IPS pada MTs di Kecamatan Mranggen yang berjumlah 31 orang. Arikunto (2002:112) menyatakan apabila subjeknya kurang dari 100, lebih baik diambil semua sehingga penelitiannya merupakan penelitian populasi. Variabel penelitian ini terdapat dua variabel yang diteliti yaitu variabel bebas dan variabel terikat. Veriabel bebas dalam penelitian ini adalah latar belakang individual dari guru IPS pada MTs di kecamatan Mranggen yang meliputi: Latar belakang pendidikan, Pengalaman mengajar,
Pengalaman pelatihan, Lingkungan Kerja. Variabel terikat dalam penelitian ini adalah kompetensi profesional guru IPS yang diuraikan menggunakan lima indikator dari kompetensi profesional guru yang terdapat dalam permendiknas No.16 tahun 2007 yaitu: Menguasai materi, struktur, konsep, dan pola pikir keilmuan yang mendukung mata pelajaran IPS, Menguasai kurikulum dan kompetensi mata pelajaran IPS, Mengembangkan materi pembelajaran secara kreatif, Mengembangkan keprofesionalan secara berkelanjutan dengan tindakan reflektif, Memanfaatkan teknologi informasi dan komunikasi untuk mengembangkan diri.

Adapun teknik pengumpulan data dalam penelitian ini menggunakan :Angket dan Wawancara. Karena pendekatan kuantitatif, maka dalam penelitian ini akan diperoleh data kuantitatif dari evaluasi kompetensi profesional guru IPS pada MTs di kecamatan Mranggen dan akan disajikan secara deskriptif. Tehnik analisis data yang dipergunakan adalah tehnik analisis kuantitatif. Adapun langkah dalam analisis data pada penelitian ini sebagai berikut: Analisis Data Deskriptif dan Analisis Uji Regresi.

\section{HASIL PENELITIAN DAN PEMBAHASAN}

\section{Hasil Penelitiam}

a. Analisis Kompetensi Profesional Guru IPS pada MTs di Kecamatan Mranggen Kabupaten Demak

Kompetensi profesional guru diukur dengan menggunakan angket yang disebarkan kepada responden sebanyak 31 guru. Kuesioner yang telah di isi oleh responden kemudian diberi skor, diolah kemudian dianalisis. Variabel kompetensi profesional guru memiliki 5 indikator, yaitu:

1. Menguasai materi, struktur, konsep, dan pola pikir keilmuan yang mendukung mata pelajaran IPS, dengan sub indikator:

a. Menguasai materi, struktur, konsep, dan pola pikir mata pelajaran IPS baik dalam lingkup lokal, nasional, maupun global. 
b. Membedakan struktur keilmuan IPS dengan ilmu-ilmu IPS

c. Menguasai konsep dan pola pikir keilmuan dalam bidang IPS

d. Menunjukkan manfaat mata pelajaran IPS

2. Menguasai kurikulum dan kompetensi mata pelajaran IPS, dengan sub indikator:

a. Memahami standar kompetensi /kompetensi Inti mata pelajaran IPS

b. Memahami kompetensi dasar mata pelajaran IPS

c. Memahami tujuan pembelajaran mata pelajaran IPS

3. Mengembangkan materi pembelajaran secara kreatif, dengan sub indikator:

i. Memilih materi pelajaran yang sesuai dengan tingkat perkembangan siswa

ii. Mengolah materi pelajaran IPS secara kreatif agar menarik dan sesuai dengan tingkat kemampuan siswa

4. Mengembangkan keprofesionalan secara berkelanjutan dengan tindakan reflektif

a. Melakukan refleksi terhadap kinerja diri secara terus menerus

b. Memanfaatkan hasil refleksi tersebut dalam rangka untuk meningkatkan keprofesionalan.

c. Melakukan penelitian tindakan kelas dalam rangka meningkatkan keprofesionalan

d. Mengikuti kemajuan zaman dengan belajar dari berbagai sumber.

5. Memanfaatkan teknologi informasi dan komunikasi untuk mengembangkan diri, dengan sub indikator:

a. Menguasai serta dapat memanfaatkan teknologi informasi dan komunikasi dalam pembelajaran IPS

b. Memanfaatkan teknologi informasi dan komunikasi untuk pengembangan keprofesionalan

Adapun interpretasi data pada variabel kompetensi profesional guru untuk tiap indiator dan sub indikator dapat dilihat pada tabel - tabel berikut:
Tabel 1 Menguasai Materi, Struktur, Konsep, dan Pola Pikir Mata Pelajaran IPS Baik Dalam Lingkup Lokal, Nasional, Maupun global.

\begin{tabular}{ccc}
\hline $\begin{array}{c}\text { Skor Alternatif } \\
\text { Jawaban }\end{array}$ & Frekuensi & Prosentase \\
\hline 5 & 13 & $42 \%$ \\
4 & 9 & $29 \%$ \\
3 & 9 & $29 \%$ \\
2 & - & - \\
1 & - & - \\
\hline
\end{tabular}

(Sumber: data yang diolah tahun 2019)

Dari Tabel 1 dapat diketahui bahwa sebanyak $42 \%$ atau 13 guru IPS memiliki skor jawaban 5 yang berarti sangat menguasai materi, struktur, konsep, dan pola piker mata pelajaran IPS baik dalam lingkup lokal, nasional maupun global. Selebihnya sebanyak masing -masing 29\% yaitu 9 orang berada dalam kategori baik dan cukup dalam penguasaan materi, struktur, konsep, dan pola piker mata pelajaran IPS baik dalam lingkup lokal, nasional maupun global.

Tabel 2 Membedakan Struktur Keilmuan IPS Dengan Ilmu-Ilmu IPS

\begin{tabular}{ccc}
\hline $\begin{array}{c}\text { Skor Alternatif } \\
\text { Jawaban }\end{array}$ & Frekuensi & Prosentase \\
\hline 5 & 13 & $42 \%$ \\
4 & 11 & $36 \%$ \\
3 & 6 & $19 \%$ \\
2 & 1 & $3 \%$ \\
1 & - & - \\
\hline
\end{tabular}

(Sumber: data yang diolah tahun 2019)

Pada Tabel 2 diketahui bahwa sebagian besar guru IPS pada MTs di Kecamatan Mranggen Kabupaten Demak yaitu 42\% atau 13 orang mampu membedakan dengan amat baik mengenai struktur keilmuan IPS dengan ilmu - ilmu IPS lainnya. Selanjutnya 35\% atau sebanyak 11 orang dalam kategori baik, 19\% atau 6 orang dalam kategori cukup dan 3\% atau 1 orang dalam kategori rendah dalam 
membedakan struktur keilmuan IPS dengan ilmi - ilmu IPS lainnya.

Tabel 3 Menguasai Konsep Dan Pola Pikir Keilmuan Dalam Bidang IPS

(Sumber: data yang diolah tahun 2019)

Dari Tabel 3 dapat dilihat bahwa sebagian besar responden yaitu guru IPS pada MTs di Kecamatan Mranggen Kabupaten Demak memiliki skor jawaban 5 dan 4 masing -masing sebesar 36\% atau 11 orang. Hal ini berarti dalam menguasai konsep dan pola piker keilmuan bidang IPS guru IPS pada MTs di Kecamatan Mranggen Kabupaten Demak termasuk dalam kategori baik. Sementara sisanya $25 \%$ atau sebanyak 8 orang berada dalam kategori cukup dan 3\% atau 1 orang kurang dalam mengusai konsep dan pola piker keilmuan bidang IPS.

Tabel 4 Menunjukkan Manfaat Mata Pelajaran IPS

\begin{tabular}{ccc}
\hline $\begin{array}{c}\text { Skor } \\
\text { Alternatif } \\
\text { Jawaban }\end{array}$ & Frekuensi & Prosentase \\
\hline 5 & 16 & $52 \%$ \\
4 & 12 & $39 \%$ \\
3 & 3 & $9 \%$ \\
2 & - & - \\
1 & - & - \\
\hline
\end{tabular}

(Sumber: data yang diolah tahun 2019)

Pada Tabel 4 dapat diketahui sebanyak $52 \%$ responden atau 16 orang memiliki skor jawaban 5, kemudian 39\% atau 12 orang memiliki skor jawaban 4 dan sisanya $9 \%$ atau 3 orang memiliki skor jawaban 3 . Hal ini berarti bahwa sebagian responden yaitu guru IPS pada MTs di Kecamatan Mranggen Kabupaten Demak, menunjukkan manfaat mata pelajaran IPS pada peserta didik.

Tabel 5 Memahami Standar Kompetensi /Kompetensi Inti Mata Pelajaran IPS

Skor Alternatif Frekuensi Prosentase Jawaban

\begin{tabular}{ccc}
\hline 5 & 7 & $23 \%$ \\
4 & 13 & $42 \%$ \\
3 & 10 & $32 \%$ \\
2 & 1 & $3 \%$ \\
1 & - & - \\
\hline Skor Alternatif & Frekuensi & Prosentase \\
Jawaban & & \\
\hline 5 & 11 & $36 \%$ \\
4 & 11 & $36 \%$ \\
3 & 8 & $25 \%$ \\
2 & 1 & $3 \%$ \\
1 & - & - \\
\hline
\end{tabular}

(Sumber: data yang diolah tahun 2019)

Tabel 5 menunjukkan bahwa 23\% responden atau 7 orang memiliki skor jawaban 5, sebanyak $42 \%$ atau 13 orang memiliki skor jawaban $4,32 \%$ atau 10 orang memiliki skore jawaban 3 dan $3 \%$ atau 1 orang memiliki skor jawaban 2. Hal ini dapat diartikan bahwa sebagian guru IPS pada MTs di Kecamatan Mranggen Kabupaten Demak memahami standar kompetensi / standar inti mata pelajaran IPS dengan baik, dan sebagian yang lainnya memahami dengan cukup.

Tabel 6 Memahami Kompetensi Dasar Mata Pelajaran IPS

\begin{tabular}{ccc}
\hline $\begin{array}{c}\text { Skor Alternatif } \\
\text { Jawaban }\end{array}$ & Frekuensi & Prosentase \\
\hline 5 & 11 & $36 \%$ \\
4 & 10 & $32 \%$ \\
3 & 10 & $32 \%$ \\
2 & - & - \\
1 & - & - \\
\hline
\end{tabular}

(Sumber: data yang diolah tahun 2019)

Dari Tabel 6 diatas dapat dilihat bahwa sebanyak $36 \%$ atau 11 orang responden memliki skor jawaban 5, 32\% responden atau 10 orang memiliki skor jawaban 4, dan 32\% responden atau 10 orang terakhir memiliki skor jwaban 3. Dalam hal ini dapat disimpulkan bahwa pemahaman guru IPS 
pada MTs di Kecamatan Mranggen Kabupaten Demak mengenai kompetensi dasar mata pelajaran IPS cukup baik.

Tabel 7 Memahami Tujuan Pembelajaran Mata Pelajaran IPS

\begin{tabular}{ccc}
\hline $\begin{array}{c}\text { Skor Alternatif } \\
\text { Jawaban }\end{array}$ & Frekuensi & Prosentase \\
\hline 5 & 16 & $52 \%$ \\
4 & 11 & $36 \%$ \\
3 & 4 & $12 \%$ \\
2 & - & - \\
1 & - & - \\
\hline
\end{tabular}

(Sumber: data yang diolah tahun 2019)

Pada Tabel 7 diketahui bahwa sebanyak $52 \%$ responden atau 16 orang memiliki skor jawaban 5, selanjutnya $36 \%$ atau 11 orang memiliki skor jawaban 4 dan sisanya $12 \%$ atau 4 orang memiliki skor jawaban 3. Hal ini dapat diartikan bahwa sebagian besar guru IPS pada MTs di Kecamatan Mranggen Kabupaten Demak memahami tujuan pembelajaran mata pelajaran IPS dengan sangat baik.

Tabel 8 Memilih Materi Pelajaran Yang Sesuai Dengan Tingkat Perkembangan Siswa

\begin{tabular}{ccc}
\hline $\begin{array}{c}\text { Skor Alternatif } \\
\text { Jawaban }\end{array}$ & Frekuensi & Prosentase \\
\hline 5 & 11 & $36 \%$ \\
4 & 12 & $39 \%$ \\
3 & 8 & $25 \%$ \\
2 & - & - \\
1 & - & - \\
\hline
\end{tabular}

(Sumber: data yang diolah tahun 2019)

Tabel 8 mnunjukkan bahwa $36 \%$ atau sebanyak 11 orang memiliki skor jawaban 5 , $39 \%$ atau 12 orang memiliki skor jawaban 4 dan $25 \%$ atau 8 orang memiliki skor jawaban 3. Dapat disimpulkan bahwa guru IPS pada MTs di Kecamatan Mranggen Kabupaten
Demak sebagian besar memilih materi pelajaran yang sesuai dengan tingkat perkembangan siswa dengan baik.

Tabel 9 Mengolah Materi Pelajaran IPS

Secara Kreatif Agar Menarik Dan Sesuai Dengan Tingkat Kemampuan Siswa

\begin{tabular}{ccc}
\hline $\begin{array}{c}\text { Skor Alternatif } \\
\text { Jawaban }\end{array}$ & Frekuensi & Prosentase \\
\hline 5 & 12 & $39 \%$ \\
4 & 9 & $29 \%$ \\
3 & 9 & $29 \%$ \\
2 & 1 & $3 \%$ \\
1 & - & - \\
\hline
\end{tabular}

(Sumber: data yang diolah tahun 2019)

Pada Tabel 9 diatas, dapat diketahui bahwa dalam mengolah materi pelajaran IPS secara kreatif agar menarik dan sesuai dengan tingkat kemampuan siswa guru IPS pada MTs di Kecamatan Mranggen Kabupaten Demak memiliki alternatif jawaban yang bervariasi. Sebanyak 39\% responden atau 12 orang memiliki skor jawaban 5 yang berarti guru mengolah materi pelajaran IPS secara kreatif agar menarik dan sesuai dengan tingkat kemampuan siswa dengan sangat baik. Selanjutnya 29\% responden atau 9 orang dengan skor jawaban , 29\% atau 9 orang dengan kor jawaban 3 serta 3\% atau 1 orang dengan skor jawaban 2 yang berarti guru mengolah materi pelajaran IPS secara kreatif agar menarik dan sesuai dengan tingkat kemampuan siswa dengan cukup baik.

Tabel 10 Melakukan Refleksi Terhadap Kinerja Diri Secara Terus Menerus

\begin{tabular}{ccc}
\hline $\begin{array}{c}\text { Skor Alternatif } \\
\text { Jawaban }\end{array}$ & Frekuensi & Prosentase \\
\hline 5 & 12 & $39 \%$ \\
4 & 11 & $36 \%$ \\
3 & 8 & $25 \%$ \\
2 & - & - \\
1 & - & - \\
\hline
\end{tabular}

(Sumber: data yang diolah tahun 2019)

Dari Tabel 10 diatas dapat dilihat bahwa $39 \%$ atau 12 orang responden memiliki skor jawaban 5, sebanyak 36\% atau 11 orang responden memiliki skor jawaban 4 
dan sisanya $25 \%$ atau 8 orang responden memiliki skor jawaban 3. Hal ini berarti bahwa sebagian besar guru IPS pada MTs di Kecamatan Mranggen Kabupaten Demak malakukan refleksi terhadap kinerja diri secara terus menerus dengan baik dan sebagian kecil dengan cukup baik.

Tabel 11 Memanfaatkan Hasil Refleksi

Tersebut Dalam Rangka Untuk Meningkatkan Keprofesionalan

\begin{tabular}{ccc}
\hline $\begin{array}{c}\text { Skor Alternatif } \\
\text { Jawaban }\end{array}$ & Frekuensi & Prosentase \\
\hline 5 & 11 & $36 \%$ \\
4 & 10 & $32 \%$ \\
3 & 10 & $32 \%$ \\
2 & - & - \\
1 & - & - \\
\hline
\end{tabular}

(Sumber: data yang diolah tahun 2019)

Pada tabel 11 diatas menunjukkan bahwa sebagian besar guru IPS pada MTs di Kecamatan Mranggen Kabupaten Demak memanfaatkan hasil refleksi tersebut dalam rangka untuk meningkatkan keprofesionalan dengan baik. Hal ini ditunjukkan dari hasil pengisian angket yaitu $36 \%$ atau 11 orang responden memiliki skor jawaban 5, 32\% atau 10 orang responden memiliki skor jawaban 4 serta $32 \%$ atau 10 orang berikutnya memiliki skor jawaban 3 .

Tabel 12 Melakukan Penelitian Tindakan Kelas Dalam Rangka Meningkatkan Keprofesionalan

\begin{tabular}{ccc}
\hline $\begin{array}{c}\text { Skor } \\
\text { Alternatif } \\
\text { Jawaban }\end{array}$ & Frekuensi & Prosentase \\
\hline 5 & 7 & $23 \%$ \\
4 & 5 & $17 \%$ \\
3 & 13 & $42 \%$ \\
2 & 3 & $9 \%$ \\
1 & 3 & $9 \%$ \\
\hline
\end{tabular}

(Sumber: data yang diolah tahun 2019)

Tabel 12 diatas menunjukkan bahwa sebanyak $23 \%$ responden atau 7 orang memiliki skor jawaban $5,17 \%$ responden atau 5 orang memiliki skor jawaban 4, 42\% responden atau 13 orang memiliki skor jawaban 3, 9\% responden atau 3 orang memiliki skor jawaban 2 dan 9\% responden terakhir atau sebanyak 3 orang memiliki skor jawaban 1. Hal ini berarti bahwa hanya sebagian kecil guru IPS pada MTs di Kecamatan Mranggen Kabupaten Demak yang melakukan Penelitian Tindakan Kelas (PTK) dalam rangka meningkatkan keprofesionalnya.

Tabel 13 Mengikuti Kemajuan Zaman Dengan Belajar Dari Berbagai Sumber.

\begin{tabular}{ccc}
\hline $\begin{array}{c}\text { Skor Alternatif } \\
\text { Jawaban }\end{array}$ & Frekuensi & Prosentase \\
\hline 5 & 15 & $48 \%$ \\
4 & 7 & $23 \%$ \\
3 & 9 & $29 \%$ \\
2 & - & - \\
1 & - & - \\
\hline
\end{tabular}

(Sumber: data yang diolah tahun 2019)

Dari Tabel 13 diatas, dapat dilihat bahwa sebanyak 48\% responden atau 15 orang memiliki skor jawaban 5, sebanyak $23 \%$ responden atau 7 orang memiliki skor jawaban 4 dan sisanya 29\% responden atau 9 orang memiliki skor jawaban 3. Hal ini menunjukkan bahwa sebagian besar guru IPS pada MTs di Kecamatan Mranggen Kabupaten Demak mengikuti kemajuan zaman dengan belajar dari berbagai sumber dengan sangat baik.

Tabel 14 Menguasai Serta Dapat Memanfaatkan Teknologi Informasi dan Komunikasi dalam Pembelajaran IPS

\begin{tabular}{ccc}
\hline $\begin{array}{c}\text { Skor } \\
\text { Alternatif } \\
\text { Jawaban }\end{array}$ & Frekuensi & Prosentase \\
\hline 5 & 10 & $32 \%$ \\
4 & 9 & $29 \%$ \\
3 & 11 & $36 \%$ \\
2 & 1 & $3 \%$ \\
1 & - & - \\
\hline
\end{tabular}

(Sumber: data yang diolah tahun 2019)

Pada Tabel 14 di atas dapat dilihat bahwa sebanyak 32\% responden atau 10 orang memiliki skor 5, sebanyak 29\% responden atau 9 orang memiliki skor 4, 36\% responden atau 11 orang memiliki skor 3 dan 
$3 \%$ responden atau 1 orang memiliki skor 2 . Hal ini dapat diartikan bahwa guru IPS pada MTs di Kecamtan Mranggen Kabupaten Demak yang mengusai serta dapat memanfaatkan teknologi informasi dan komunikasi dalam pembelajaran IPS dengan sangat baik sebanyak 10 orang, sebanyak 9 orang dengan baik, 11 orang dengan cukup dan 1 orang dengan kemapuan kurang.

Tabel 15 Memanfaatkan Teknologi Informasi dan Komunikasi untuk Pengembangan Keprofesionalan

\begin{tabular}{ccc}
\hline $\begin{array}{c}\text { Skor Alternatif } \\
\text { Jawaban }\end{array}$ & Frekuensi & Prosentase \\
\hline 5 & 11 & $36 \%$ \\
4 & 11 & $36 \%$ \\
3 & 8 & $25 \%$ \\
2 & 1 & $3 \%$ \\
1 & - & - \\
\hline \multicolumn{2}{l}{ (Sumber: data yang diolah tahun 2019) }
\end{tabular}

Pada Tabel 15 diatas, yaitu item memanfaatkan teknologi informasi dan komunikasi untuk pengambangan keprofesionalan, guru IPS pada MTs di Kecamatan Mranggen Kabuaten Demak memiliki jawaban yang beragam. Sebanyak $36 \%$ atau 11 orang memiliki skor 5 yang berarti sangat baik dalam memanfaatkan teknologi informasi dan komunikasi untuk pengambangan keprofesionalan, $36 \%$ atau 11 orang selanjutnya memiliki skor 4 yang berarti baik dalam memanfaatkan teknologi informasi dan komunikasi untuk pengambangan keprofesionalan, 25\% atau 8 orang memiliki skor 3 yang berarti cukup dalam memanfaatkan teknologi informasi dan komunikasi untuk pengambangan keprofesionalan, serta $3 \%$ atau 1 orang memiliki skor 2 yang berarti kurang dalam memanfaatkan teknologi informasi dan komunikasi untuk pengambangan keprofesionalan.

Lebih lanjut, evaluasi terhadap kompetensi profesional guru IPS pada MTs di Kecamatan Mranggen Kabupaten Demak yang sesuai dengan permendiknas no 16 tahun 2007 dapat dilihat pada tabel 16 mengenai indikator kompetensi profesional guru IPS sebagai berikut:

Tabel 16 Tabel Indikator Kompetensi Profesional Guru IPS

\begin{tabular}{|c|c|c|}
\hline Indikator & Prosentase & $\begin{array}{c}\text { Jumlah } \\
\text { Guru }\end{array}$ \\
\hline $\begin{array}{l}\text { Menguasai materi, } \\
\text { struktur, konsep, dan } \\
\text { pola pikir keilmuan } \\
\text { yang mendukung } \\
\text { mata pelajaran IPS }\end{array}$ & $42 \%$ & 13 \\
\hline $\begin{array}{l}\text { Menguasai kurikulum } \\
\text { dan kompetensi mata } \\
\text { pelajaran IPS, } \\
\text { mengembangkan } \\
\text { materi pembelajaran } \\
\text { secara kreatif }\end{array}$ & $35 \%$ & 11 \\
\hline $\begin{array}{l}\text { Mengembangkan } \\
\text { materi pembelajaran } \\
\text { secara kreatif }\end{array}$ & $19 \%$ & 6 \\
\hline $\begin{array}{l}\text { Mengembangkan } \\
\text { keprofesionalan } \\
\text { secara berkelanjutan } \\
\text { dengan tindakan } \\
\text { reflektif }\end{array}$ & $26 \%$ & 8 \\
\hline $\begin{array}{l}\text { Memanfaatkan } \\
\text { teknologi informasi } \\
\text { dan komunikasi untuk } \\
\text { mengembangkan diri }\end{array}$ & $29 \%$ & 9 \\
\hline
\end{tabular}

Tabel 16 diatas menunjukkan bahwa indikator menguasai materi, struktur, konsep, dan pola pikir keilmuan yang mendukung mata pelajaran IPS memiliki prosentase yang paling besar yaitu $42 \%$ atau sebanyak 13 orang guru dari 31 orang, menganggap bahwa menguasai materi dan keilmuan merupakan hal yang paling penting dalam menunjukkan kompetensi profesional mereka sebagai guru. Selanjutnya indikator menguasai kurikulum dan kompetensi mata pelajaran IPS, mengembangkan materi secara kreatif sebanyak 35\%. Artinya bahwa guru IPS pada MTs di Kecamtan Mranggen Kabupaten Demak yang menguasai kurikulum dan kompetensi mata pelajaran IPS, mengembangkan materi pembelajaran secara 
kreatif dengan sangat baik adalah 11 orang guru dari 31 orang. Berikutnya sebanyak 19\% atau hanya 6 dari 31 orang guru IPS pada MTs di Kecamatan Mranggen Kabupaten Demak yang mengembangkan materi pembelajaran secara kreatif dengan sangat baik. Untuk indikator mengembangkan keprofesionalan secara berkelanjutan dengan tindakan reflektif hanya $26 \%$ arau 8 dari 31 orang. Kemudian untuk indikator memanfaatkan teknologi informasi dan komunikasi untuk mengembangkan diri adalah sebanyak 29\% atau hanya 9 dari 31 guru yang melakukannya dengan sangat baik, selebihnya dalam kategori baik, cukup maupun kurang.

Adapun kompetensi profesional guru berdasarkan permendiknas No.16 tahun 2007 dapat dilihat pada tabel 17 berikut:

Tabel 17 Kompetensi Profesional Guru IPS

\begin{tabular}{|l|c|c|}
\hline Kategori & Jumlah Guru & Prosentase \\
\hline $\begin{array}{l}\text { Amat } \\
\text { Baik }\end{array}$ & 10 & $32,2 \%$ \\
\hline Baik & 8 & $25,8 \%$ \\
\hline Cukup & 11 & $35,5 \%$ \\
\hline Sedang & 2 & $6,5 \%$ \\
\hline Kurang & 31 & 0 \\
\hline
\end{tabular}

Sumber: Data yang diolah (2019)

Berdasarkan tabel 17 di atas dapat dilihat bahwa sebanyak $32,2 \%$ atau 10 orang guru dari 31 orang guru masuk dalam kategori amat baik tingkat profesionalnya. Selanjutnya $25,8 \%$ atau 8 orang guru dari 31 orang guru berada dalam kategori baik kompetensi profesionalnya, $35,5 \%$ atau 11 orang guru dari 31 orang guru masuk dalam kategori cukup kompetensi profesinalnya. Dan 6,5\% atau 2 orang guru dari 31 orang guru memiliki kategori sedang dalam kompetensi profesionalnya. Hal ini dapat diinterpretasikan bahwa kompetensi profesional guru IPS pada MTs di Kecamatan Mranggen Kabupaten Demak tertinggi terdapat pada kategori cukup yaitu 35,5\% atau 11 orang.

\section{b. Analisis Latar Belakang Individual Guru yang Membentuk Kompetensi Profesional Guru IPS Pada MTs di Kecamatan Mranggen Kabupaten Demak}

Dalam penelitian ini juga di ukur bagaimana faktor latar belakang individual memiliki pengaruh yang sangat signifikan terhadap pembentukan kompetensi profesional guru IPS pada MTs di Kecamatan Mranggen Kabupaten Demak. Terdapat empat latar belakang individual guru IPS pada MTs di Kecamatan Mranggen Kabupaten Demak yang membentuk kompetensi profesional meliputi: latar belakang pendidikan, pengalaman mengajar, pengalaman pelatihan, dan lingkungan kerja.

Uji t dilakukan untuk melihat seberapa jauh pengaruh satu variabel independen yaitu latar belakang individual guru secara individu menerangkan variasi variabel dependen atau variabel kopetensi profesional guru IPS. Uji t pada penelitian ini dirangkum secara terperinci dalam Tabel 4.7 berikut:

Tabel 4.24 Uji t

\begin{tabular}{|c|c|c|c|c|c|c|}
\hline Variabel & Koefisien & $\mathrm{R}^{2}$ & $\begin{array}{c}\text { Std. } \\
\text { Error }\end{array}$ & $\begin{array}{c}\mathrm{t}- \\
\text { statistik }\end{array}$ & P-Value & Keterangan \\
\hline $\mathrm{X} 1$ & 1,800 & $25.80 \%$ & 0,759 & 2,373 & 0,025 & Signifikan \\
\hline $\mathrm{X} 2$ & 2,575 & $44.63 \%$ & 0,438 & 5,882 & 0,000 & Signifikan \\
\hline $\mathrm{X} 3$ & 0,079 & $0.35 \%$ & 0,311 & 0,255 & 0,800 & $\begin{array}{c}\text { Tidak } \\
\text { Signifikan }\end{array}$ \\
\hline $\mathrm{X} 4$ & 1,995 & $31.16 \%$ & 0,500 & 3,989 & 0,000 & Signifikan \\
\hline \multicolumn{6}{|c|}{ Daerah kritis ditolak jika p-value $<\alpha=0.05$} \\
\hline
\end{tabular}

Sumber : data yang diolah (2019)

Keterangan:

$\mathrm{X} 1$ : latar belakang pendidikan

$\mathrm{X} 2$ : pengalaman mengajar

X3: pengalaman pelatihan

$\mathrm{X} 4$ : lingkungan kerja

Berdasarkan Tabel 4.7 diatas menunjukkan bahwa variabel latar belakang pendidikan berpengaruh terhadap kompetensi profesional guru IPS dengan $\mathrm{p}$ value sebesar 0,025 yang lebih kecil dibanding $\alpha=0,05$. variabel pengalaman mengajar berpengaruh terhadap kompetensi profesional guru IPS dengan p-value sebesar 
0,000 yang lebih kecil dibanding $\alpha=0,05$. variabel pengalaman pelatihan tidak berpengaruh terhadap kompetensi profesional guru IPS dengan p-value sebesar 0,800 yang lebih besar dibanding $\alpha=0,05$, dan variabel lingkungan kerjaberpengaruh terhadap kompetensi profesional guru IPS dengan $p$-value sebesar 0,000 yang lebih kecil dibanding $\alpha=0,05$. Pengaruh tertinggi terhadap variabel kompetensi profesional guru IPS dapat dilihat pada kolom $R^{2}$ nya, sehingga dapat disimpulkan variabel pengalaman mengajar merupakan variabel yang memberikan pengaruh tertinggi terhadap variabel kompetensi profesional guru IPS.

Lebih lanjut latar belakang individual guru yang mempengaruhi kompetensi profesional guru IPS dilihat pada Tabel 4.24 di bawah ini:

Tabel 4.25 Persentase Pengaru Faktor Latar Beakang Individual Guru terhadap Kompetensi Profesional Guru IPS

Latar Belakang Individual Persentase
Guru IPS

\begin{tabular}{lr}
\hline Pengalaman Mengajar & $44,63 \%$ \\
\hline Lingkungan Kerja & $31,16 \%$ \\
\hline Latar Belakang Pendidikan & $25,80 \%$ \\
\hline Pengalaman Pelatihan & $0,35 \%$ \\
\hline \multicolumn{2}{c}{ Sumber: Data yang diolah $(2019)$}
\end{tabular}

Dalam Tabel 4.24 di atas dapat dilihat bahwa pengalaman mengajar memiliki prosentase terbesar yaitu 44,63\%. Lingkungan kerja memiliki prosentase sebesar 31,16\%. Berikutnya adalah latar belaknag pendidikan, yang memiliki prosentase sebesar 25,80\% dalam pembentukan kompetensi profesional guru IPS pada MTs di Kecamatan Mranggen Kabupaten Demak, dilanjutkan dengan pengalaman pelatihan memberikan prosentase yang sangat kecil yaitu sebesar $0,35 \%$. Hal ini berarti pengalaman pelatihan memiliki pengaruh yang kurang siqnifikan terhadap pembentukan kompetensi profesional guru IPS di Kecamatan Mranggen Kabupaten Demak.

\section{c. Pembahasan}

Menurut Mohammad Nadeem (2011) Guru merupakan komponen paling penting dari sistem pendidikan mana pun. Seberapa baik mereka mengajar tergantung pada motivasi, kualifikasi, pengalaman, pelatihan, bakat dan banyak faktor lain, tidak sedikit dari ini menjadi lingkungan dan struktur manajemen dengan mana mereka melakukan peran mereka. Guru harus dilihat sebagai bagian dari solusi, bukan bagian dari masalah. Bayaran yang buruk, status rendah dan moral adalah penyebab utama buruknya kinerja dan perilaku korupsi di sektor publik. Di seluruh dunia, jutaan guru, kebanyakan dari mereka perempuan, bekerja tanpa lelah untuk upah kemiskinan yang mendidik generasi berikutnya.

Lebih lanjut Anthoni Bordoh (2015) berpendapat bahwa Ilmu Sosial berpusat pada masalahkelangsungan hidup individu dalam masyarakat dan perkembanganpikiran dan keterampilan positif terhadap solusi mereka. Guru perlu memahami secara mendalam tentangsubjek dan / pendekatan haknya untuk pengajarankonten seperti yang ditentukan kepadanya.

Berdasarkan hasil penelitian menunjukkan bahwa sebagian besar guru IPS pada MTs Kecamatan Mranggen Kabupaten Demak memiliki kompetensi profesional yang cukup yaitu sebesar 35,5 \%, dengan kompetensi professional amat baik sebesar $32,2 \%$, dilanjutkan dengan kategori baik sebesar 25,8\% dan kategori sedang sebanyak $6,5 \%$. Data tersebut sejalan dengan Nolan dan Hoover (2011 : 7) bahwa evaluasi akan memberikan jaminan bahwa setiap guru setidaknya akan memiliki kinerja sesuai dengan standar minimal kompetensi. Sementara itu Penelitian dari Kelly A. Parkes mengenai performance assessment: lessons from performers menunjukkan bahwa penilaian kinerja yang baik akan memberikan umpan balik bagi peserta didik salah satunya pada hasil belajar peserta didik. Selain itu, penilaian kinerja yang baik juga akan memberikan efek yang positif pada kinerja rekan sejawat Berdasarkan penelitian ini, 
penilaian kinerja guru memberikan manfaat yang sangat besar.

Meningkatkan profesionalisme guru merupakan hal yang sangat penting, karena menyangkut masalah hasil kerja guru yang merupakan salah satu langkah dalam meningkatkan mutu pelayanan kepada siswa. Profesionalisme guru berkaitan erat dengan output hasil pendidikan yang diharapkan masyarakat. Evaluasi guru memungkinkan bagi guru yang memiliki kinerja dibawah standar minimal, bisa melakukan refleksi dan memperbaiki kinerjanya.

Lebih lanjut menururt Cut Fitriani, (2017) kompetensi profesional seorang guru adalah seperangkat kemampuan yang harus dimiliki oleh seorang guru agar dapat melaksanakan tugas mengajar dengan berhasil. Kompetensi profesional guru juga dapat diartikan sebagai kemampuan penguasaan materi pembelajaran secara luas dan mendalam yang memungkinkan membimbing peserta didik memenuhi standar kompetensi yang ditetapkan dalam Standar Nasional Pendidikan (Mulyasa, 2009).

Pengalaman mengajar dan lingkungan kerja merupakan faktor pembentuk kompetensi profesional guru IPS di Kecamatan Mranggen Kabupaten Demak. Maka dari itu langkah awal mengembangkan sistem evaluasi guru komprehensif tunggal untuk membentuk standar bagi guru yang konsisten dengan standar untuk pembelajaran siswa, karena semua kegiatan mengajar pada akhirnya bertujuan untuk meningkatkan pembelajaran siswa. Sistem evaluasi dengan standar untuk pengajaran yang selaras dengan pembelajaran siswa memungkinkan guru untuk fokus mendukung pembelajaran siswa mereka, daripada hanya berkonsentrasi pada praktik pengajaran mereka sendiri. Kerja kolaboratif antar guru dalam lingkungan kerja untuk pembelajarandan bertukar strategi dan keterampilan mengajar baru mungkin sangat efektifdan cara praktis pengembangan profesional.Hee Jun Choi\& Ji-Hye Park (2016).
Dalam penelitian ini masih banyak terdapat keterbatasan untuk dapat diperbaiki pada penelitian yang akan datang. Diantaranya jumlah populasi dan sampel yang masih sedikit, sehingga belum mencerminkan keadaan yang sebenarnya. Disisi lain, pengambilan data menggunakan angket yang terkadang tidak menunjukkan keadaan sebenarnya.

\section{PENUTUP}

\section{Simpulan}

Kompetensi 47rofessional guru IPS pada MTs di kecamatan Mranggen Kabupaten Demak berada pada kategori cukup yaitu sebesar 35,5 \%, kategori amat baik sebesar $32,2 \%$, baik $25,8 \%$, dan sedang $6.5 \%$. Hal ini sangat jauh dari harapan pemerintah yang mengharapkan bahwa kompetensi 47rofessional guru hendaknya berada pada kategori amat baik dan baik dalam penilaian kinerjanya.

Latar belakang individual guru yang membentuk kompetensi 47rofessional guru IPS di Kecamatan Mranggen Kabupaten Demak yaitu meliputi: latar belakang pendidikan, pengalaman mengajar, pengalaman pelatihan, dan lingkungan kerja. Masing - masing dari 47rofessi tersebut memiliki prosentase dalam pembentukan kompetensi 47rofessional guru IPS pada MTs di Kecamatan Mranggen Kabupaten Demak yang meliputi: latar belakang pendidikan sebanyak 25,80\% , pengalaman mengajar sebanyak 44,63\%, pengalaman pelatihan sebanyak 0,35 \% dan lingkungan kerja sebanyak $31,16 \%$.

\section{Saran}

Adapaun saran untuk meningkatkan profesionalisme guru, yaitu:

1. Bagi Guru, hasil penelitian ini dapat dijadikan sebagai bahan masukan guru IPS utamanya guru IPS di Kecamatan Mranggen Kabupaten Demak untuk mengetahui faktor-faktor pembentuk profesionalisme guru serta mengantisipasi kendala-kendala yang 
dihadapi dalam meningkatkan kompetensi profesional.

2. Bagi Sekolah, hasil penelitian ini dapat dijadikan sebagai bahan masukan bagi sekolah dalam upaya meningkatkan profesionalisme guru, agar menjadi lebih baik.
3. Bagi Pemerintah,penelitian ini dapat dijadikan masukan dan evaluasi dalam pengambilan kebijakan guna meningkatkan kualitas sumber daya manusia.

\section{DAFTAR PUSTAKA}

Ahmad Barizi. 2009. Menjadi Guru Unggul. Yogyakarta : Ar Ruzzmedia

Anas Sudijono. 1987. Statistik Pendidikan. PT Raja Grafindo Persada : Jakarta

Arikunto, S. 2012. Dasar-Dasar Evaluasi Pendidikan. Bumi Aksara: Jakarta

Bordoh, Anthony, Isaac Eshun, Sylvanus Kofie, Thoephilus Kweku Bassaw,and Patrick Kwarteng . 2015. Social Studies Teachers' Content Knowledge in Senior High Schools in the SekondiTakoradi Metropolis in the Western Region of Ghana. American Journal of Social Science ResearchVol. 1, No. 3, 2015, pp. 169-177.

Christopher M. Clark dan Tuba Gökmenoğlu. 2015. Teachers' Evaluation of Professional Development Insupport of National Reforms. Issues in Educational Research, 25(4).

Darling-Hammond, L. 2013. Getting teacher evaluation right: What really matters for effectiveness and improvement. New York: Teachers College Press.

Edi, Hendri. 2010. Guru Berkualitas : Profesional dan Cerdas Emosi. Jurnal Sang Guru.Vol 1 No.2 $2010 \mathrm{Hal}: 1-11$. UPI

Eko Pramono, Suwito. 2012. Hakikat Pendidikan Ilmu Pengetahuan Sosial. Semarang: Widya karya

Fitriani, Cut, Murniati dan Nasir Usman. 2017. Kompetensi Profesional Guru Dalam Pengelolaan Pembelajaran Di MTs Muhammadiyah Banda Aceh. Jurnal Magister Administrasi pendidikan Pascasarjana Universitas Syiah Kuala vol. 5 no. 2.

Hee Jun Choi dan Ji-Hye Park. 2016. An Analysis of Critical Issues in Korean Teacher Evaluation Systems. c e p s Journal Vol.6 No2 Year 2016151.

Jejen Musfah. 2011. Peningkatan Kompetensi Guru. Jakarta: Kencana.

Johanes Konig. 2016. Teachers' Professional Knowledge for Teaching English as a Foreign Language: Assessing the Outcomes of Teacher Education" Journal of Teacher Education 1-18 (C) 2016 American Association of Colleges for Teacher Education.

Mohammad Nadeem . 2011. Teacher's Competencies and Factors Affecting the Performance of Female Teachers in Bahawalpur (Southern Punjab) Pakistan. International Journal of Business and Social Science, Vol. 2 No. 19 [Special Issue - October 2011].

Mulyasa. 2009. Standar Kompetensi Sertifikasi Guru. Bandung: Remaja Rosdakarya.

Nolan, James F. \& Hoover, Linda A. 2011. Teacher Supervision And Evaluation: Theory Into Practice. Hoboken: John Wiley \& Sons, Inc.

Nurkholisah. 2017. Implementasi Profesionalitas Guru Pendidikan Agama Islam Paska Sertifikasi Guru di Madrasah Tsanawiyah Negeri Kota Binjai. Analytica Islamica Vol. 6 No. 2. 
Oemar Hamalik. 2003. Proses Belajar Mengajar. Jakarta: Bumi Aksara.

Parkes, Kelly A. 2010. Performance assessment: lessons from performers (jurnal). International Journal of Teaching and Learning in Higher Education, Volume 22.

Permendiknas Nomor 16 Tahun 2007 Tentang Standar Kualifikasi Akademik dan Kompetensi Guru.

Pramono, Harry. 2012. Pengaruh Sistem Pembinaan, Sarana Prasarana Dan Pendidikan Latihan Terhadap Kompetensi Kinerja Guru Pendidikan Jasmani Sekolah Dasar Di Kota Semarang. Jurnal Penelitian Pendidikan. Vol. 29 Nomor 1 tahun 2012 Hal : 7-16. Universitas Negeri Semarang.

Pramono, Suwito Eko. 2014. Kinerja Guru Sejarah: Studi Kausal Pada Guru-guru Sejarah SMA. Jurnal Paramita, 2014: 114-125. Universitas Negeri Semarang.

Siswanto Sastrohadiwiryo. 2005. Manajemen Tenaga Kerja Indonesia Pendekatan Administratif dan Operasional. Jakarta: Bumi Aksara.

Sugiono. 2008. Metode Penelitian Kuantitatif, Kualitatif, dan R\&D. Bandung : Alfabeta.

Sudarwan Danim. 2002. Inovasi Pendidikan Dalam Upaya Peningkatan Profesionalisme Tenaga Kependidikan. Bandung : Pustaka Setia.

Tiara, Anggia Dewi. 2015. Pengaruh Profesionalisme Guru dan Motivasi Kerja Terhadap Kinerja Guru Ekonomi SMA se-kota Malang. Jurnal Promosi Vol.3.No.124-35.

Tuba Gökmenoğlu, Christopher M. Clark. 2015. Teachers' Evaluation Of Professional Development In Support Of National Reforms. Issues in Educational Research, 25(4).

Undang-Undang RI Nomor 20 Tahun 2003 Tentang Sistem Pendidikan Nasional.

Winarsih, S Mulyani. 2012. Peningkatan Profesionalisme Guru IPA Melalui Lesson Study Dalam Pengembangan Model Pembelajaran PB. Jurnal JPII, 2012: 1 (1) 43-50. Universitas Negeri Semarang. 